\title{
Compilation, Research, Development and Utilization of Documents and Archives in Military Universities
}

\author{
Qianqian Zhao ${ }^{1 *}$, Quan Wen ${ }^{1}$, Yuan Zhao ${ }^{1}$, Qiang $\mathrm{Wei}^{1}$ \\ ${ }^{1}$ Experimental Training Base of School of Information and Communication, National University of Defense \\ Technology, Xi 'an, Shaanxi, China \\ "Corresponding author. Email: 277747543@qq.com
}

\begin{abstract}
The scientific compilation, research and efficient development and utilization of document files in military academies play an important role in maintaining the systematicness and effectiveness of document files, enhancing the function of file service, improving the level of file business and improving the quality of file personnel. Article on the basis of studying archives management, service archives, studying form, talents construction and so on four aspects has carried on the questionnaire survey and analysis, found that studying documents form a single, traditional way, "make up" light "r", lack of talents and so on, puts forward to developing system and efficient development strategy, strengthen study, studying strong-built team, Better serve the development of military academies.
\end{abstract}

Keywords: Archives compiling-studying, Documentary archives, Military academies.

\section{THE RESEARCH DESIGN}

In order to deeply understand the current situation of document editing and research work in military academies, analyze the problems existing in file editing and research work and explore the development path, this paper adopts questionnaire survey to investigate this topic.

The questionnaire survey is mainly aimed at archival professionals in military academies and carried out on the platform of Wenjuanxing (as shown in Table 1). A total of 14 subjective and objective questions are set for archival compilation and research, including 11 objective questions and 3 subjective questions. In addition, some archivists were interviewed on the spot. A total of 100 paper and electronic questionnaires were distributed, and 85 valid questionnaires were received with a recovery rate of $85 \%$. The author comprehensively sorted out the collected questionnaires, and systematically combed the research results from four aspects, including the form, method, Angle and talent training of archival compilation and research.

\section{THE SIGNIFICANCE OF ARCHIVAL COMPILATION AND RESEARCH}

Archival compilation and research is an important way to develop and utilize archival information resources and expand archival information service functions, which can effectively improve the integration rate of archival information resources, strengthen archival protection and enhance the influence of archives.

\subsection{Enhance the effectiveness of archival preservation management}

In the question of "the function and significance of archival compilation and research", the proportion of "strengthening the effectiveness of archival preservation and management" is as high as 92\%. Archival compilation and research is an effective way to protect archival historical materials and make them easy to use. It can greatly reduce the repeated use of original files, avoid wear and tear, prolong their life, and benefit the permanent preservation and use of original files [1]. The contents and utilization of document archives management in military academies are very complicated. Only with the help of scientific compilation and research can centralized and systematic management of resources be realized and the value of 
archives development and utilization be effectively enhanced.

Table 1. Questionnaire design form for compiling documents and files in military academies

\begin{tabular}{|c|c|c|}
\hline icators & Research focus & h content \\
\hline $\begin{array}{l}\text { The contribution of archives } \\
\text { compilation and research to the } \\
\text { promotion of archives } \\
\text { management }\end{array}$ & $\begin{array}{l}\text { To investigate the influence of the process } \\
\text { and results of archival compilation and } \\
\text { research on archival management from } \\
\text { "significance and importance of archival } \\
\text { compilation and research" }\end{array}$ & $\begin{array}{l}\text { 1. The effect of archival compilation and } \\
\text { research on document archives protection; } \\
\text { 2. the effect of improving the management } \\
\text { level of documents and archives. }\end{array}$ \\
\hline $\begin{array}{l}\text { Contribution of archival } \\
\text { compilation and research to } \\
\text { archival service function }\end{array}$ & $\begin{array}{l}\text { To investigate the contribution of archival } \\
\text { editing and research to improve archival } \\
\text { service efficiency from the perspective of } \\
\text { "utilization of archival editing and research } \\
\text { achievements" }\end{array}$ & $\begin{array}{l}\text { 1.Utilization efficiency of archive } \\
\text { compilation and research results; } \\
\text { 2.Methods of compiling and selecting } \\
\text { topics for archives. }\end{array}$ \\
\hline $\begin{array}{l}\text { Forms and methods of archivall } \\
\text { compilation and research }\end{array}$ & $\begin{array}{l}\text { Investigate the purpose and effect of archival } \\
\text { compilation and research from the form and } \\
\text { method of "archival compilation and research } \\
\text { results" }\end{array}$ & $\begin{array}{l}\text { 1.File compilation research results form; } \\
\text { 2.Archival compilation and research } \\
\text { methods; } 3 \text {. The organization of archives } \\
\text { compilation and research. }\end{array}$ \\
\hline $\begin{array}{l}\text { Archival compilation and } \\
\text { research work and archival } \\
\text { talent team construction }\end{array}$ & $\begin{array}{l}\text { From the point of view of the requirements of } \\
\text { the construction and development of talent } \\
\text { team, this paper studies the mutual influence } \\
\text { of archival compilation and research work } \\
\text { and talent construction }\end{array}$ & $\begin{array}{l}\text { 1.The staffing of archivists; } 2 \text {. Professional } \\
\text { background in file management; } 3 \text {. The } \\
\text { function of archival compilation and } \\
\text { research to enhance personnel's } \\
\text { professional level; } 4 \text {. The requirements of } \\
\text { archival talents for archival compilation and } \\
\text { research. }\end{array}$ \\
\hline
\end{tabular}

\subsection{Enhance the function of archives service}

$82 \%$ of the respondents chose to "enhance the utilization function of archives service". Archival compilation and research is an important way to provide better utilization of archival services. Document editing and research provide data support services for the work of various business departments of colleges and universities, and enhance the influence of document editing and research in the work of colleges and universities. The compilation and research work can provide the compilation and research results for the military academies, so that the majority of staff see the value of archives, realize the importance of archives work, and play a role in publicity and education[2]. In the process of compilation and research of documents and archives, it follows the Regulations on The Management of Military Archives, reasonably classifies and constructs differentiated series and main materials, so as to provide accurate services for the development and utilization of resources by users, better serve the decision-making of units, maintain the comprehensiveness of data and improve work efficiency.

\subsection{Improve the level of archives}

The choice of "perfect archival business work" accounted for $60 \%$. Archival compilation and research work can check again the collection, sorting, identification, management and other work of archives, examine the specific problems that may exist in the basic work of archives, deepen the understanding and application of theories and methods of archives management, improve and perfect the basic work, and enhance the level of archives management. Some compiling and researching projects also have the function of rescuing and saving archives, supplementing and perfecting the missing archival information through compiling and researching archives.

The archival work in colleges and universities has been focused on keeping and paying attention to the entity management of archives. It is not only beneficial to the preservation of the original documents, but also to improve the utilization efficiency, increase the service strength of the archives work, and perfect the function of the archives management department. 


\section{ARCHIVES RESEARCH EXISTING PROBLEMS}

At present, archives management departments have been established in all military academies and colleges, basically meeting the general requirements of "integrity, systematization, standardization, information and network". However, there are some phenomena in archives compilation and research work, such as "good but not popular" and "important and not paying attention to".

\subsection{The form of compilation and research is single}

In the form of archival compilation and research, events accounted for $45 \%$, organization evolution accounted for $23.7 \%$, document compilation accounted for $19.5 \%$, topic selection is often limited to basic compilation, compilation and collection. It is easy to lead to simple compilation and research mode, single service mode and lack of in-depth excavation, analysis and research on archive data [3]. Most of the compilation and research results are systematic and professional, long and unreadable, making readers recoile.

$86.5 \%$ of the research results are paper carriers, which is quite different from the current electronic mainstream media. Compared with local colleges and universities, the degree of digital application of archival editing and research in military colleges and universities is low, the content of editing and research lacks vividness, and the display form lacks flexibility. The publicity of archive compilation and research achievements needs to be strengthened. Only $14.5 \%$ choose new social media and three-dimensional publicity of network environment, and many compilation and research achievements are difficult to play an effective role.

\subsection{The way of compiling and researching is traditional and the way of compiling and researching is old}

Archives compilation and research in essence is to provide services for the development and utilization of business work of various departments. But in the actual work, the proportion of compiling and researching according to the archives is $89 \%$, and the proportion of compiling and researching according to the demand of business departments is only $12 \%$.Archives management departments are sometimes limited to the Treasury resources, and they only compile and research for the purpose of compilation and research, and lack understanding of utilization requirements, resulting in low utilization rate of compilation and research products, and difficulty in fully showing the practical significance and practical value of compilation and research results. Traditional document archival work focuses on storage, and a large amount of archival information cannot be developed timely and effectively. Archival information resources do not give full play to the value of utilization, can not meet the multi-angle, multi-level demand, archives compilation and research results are not high satisfaction.

\subsection{File editing and research depth is not enough, emphasis on "editing" and light on "research"}

The compilation and research of archives is mainly about integration, editing and processing, accounting for $78 \%$, and analysis and research account for $22 \%$. At present, the compilation and research of documents in military academies is still mainly based on editing. Editing builds the foundation for research, research provides the basis for compilation, and only the combination of compilation and research can guarantee the high quality and efficiency of archive compilation and research results [4]. To conduct in-depth research on archival resources, it is necessary to combine editing and research organically to form systematic editing and research results. But at present, the majority of documents and archives compilation and research achievements are more than compilation and less than research. It is precisely because most archives compilation and research work only compilation but not research, the combination of "compilation" and "research" is weak, resulting in the lack of breadth and depth of archives compilation and research data, and the overall quality urgently needs to be improved.

\section{DO A GOOD JOB IN COMPILING AND RESEARCHING ARCHIVES}

Taking the archives compilation and research work of our college as an example, the college has undergone several adjustments and reforms. Since its establishment, the college leaders have attached great importance to the archives construction, given strong support and input, and have completed the software and hardware construction of the archives room, and visited the archives room for inspection and guidance for many times.

\subsection{Change passive archival compiling research to active archival service}

To fully meet the needs of users is the primary purpose of archival compilation and research. Archivists should actively analyze the actual needs of military academy development for archival information resources from a scientific perspective of archival culture, so as to provide scientific and practical archival compilation and research products. In the actual work of archival compilation and research, we should 
understand archival compilation and research work, plan archival compilation and research work, and do archival compilation and research work well from the Angle of excavating archival resources and improving the utilization level, so as to make the achievements of archival compilation and research become the driving force of the development of colleges and universities.

\subsection{Strengthen archives organization construction}

It is necessary to actively set up the research force of document archives, deepen, refine and implement the research, development and utilization of document archives in military academies. First of all, editing and research personnel should establish correct value cognition of archival work, enhance decision-making thinking, apply advanced information technology and means, efficiently integrate document archive information resources, and realize convenient operation of archive query and utilization [5]. Secondly, with a high sense of responsibility and mission, the editing and research personnel should actively sort out and enrich the contents of documents and files of military academies, ensure the scientific and integrity of compiled materials, and give full play to their post functions. Thirdly, strengthen the leadership of archival compilation and research work, improve the management methods of archival compilation and research work, establish a long-term mechanism of archival compilation and research work, make the compilation and research work on the road of normalization. Responsible leaders personally select and participate in the compilation of research projects and results of acceptance and evaluation. Set up full-time personnel responsible for archives compilation and research management to ensure the effective and orderly development of the work.

\subsection{Increase the research efforts of archives compilation and research}

In archival compilation and research work, "compilation" and "research" are closely related and inseparable. Archives management is to make better use of archives, while the compilation and research work is to provide more targeted, systematic and proactive service of archives utilization. At present, the compilation and research work of documents and archives is mainly to edit, compile and sort out information, so as to improve the value and efficiency of archival information utilization. However, this does not mean that there is no need for research and expansion, nor does it mean to reduce the weight of research, but to combine editing and research closely [6]. No matter compiling the history of the school or compiling the reference materials for archival compilation, it is necessary to deeply study the archival content. In order to produce high-quality archives compilation and research results, it is necessary to adhere to the combination of compilation and research and intensify research efforts.

\section{CONCLUSION}

According to the survey results, the compilation and research of documents in military academies is widely recognized and carried out by all units, which is conducive to improving the efficiency of archives utilization and service functions, but there are still problems such as single compilation and research form and traditional compilation and research method. In the new development period, in order to establish long-term and stable archival information service, it is necessary to change passive archival research into active service, systematically manage and three-dimensional archival research, strengthen the construction of archival research team, effectively improve the quality of archival research, development and utilization, and better serve the needs of information service and development decision-making of military academies.

\section{REFERENCES}

[1] Xia, Min. (2021) Cognition and practice of science and technology archives compilation and research mode. Electromechanical military ship archives, 04: 58-60.

[2] Xue, Jingwen. (2020) Archives study the ways and methods of conducting archival exhibitions. Inside and outside the file, 30: 20.

[3] Yan, Chang., Wang, Weiwei. (2021) Research and Analysis of Continuing Education for Archives Professionals. Zhejiang Archives, 04: 58-60.

[4] Huo, Qi dao., Xu, Wen. (2021) Construction and realization of physical archives education and publicity function in Universities. Industry and Technology Forum, 20 (15): 279-280.

[5] Gong, Huwei., Shen, Chengcheng. (2021) Analysis of the compilation and research of archives information resource development of major construction projects-- takes the unit affiliated to the Chinese Academy of Sciences as an example. Urban Construction Archives, 06: 63-65.

[6] Li, Qian. (2021) Exploration of file compilation and research work oriented by the needs of hospital decision makers----takes the archival work of Hainan Provincial People's Hospital as an example. Inside and outside the file, 17: 7072 . 